\title{
Eocene ungulate mammals from West Antarctica: implications from their fossil record and a new species
}

\author{
JAVIER N. GELFO ${ }^{1,2,3}$, GUILLERMO M. LÓPEZ ${ }^{2,3}$ and SERGIO N. SANTILLANA ${ }^{4}$ \\ ${ }^{I}$ CONICET, Consejo Nacional de Investigaciones Cientificas y Técnicas, Buenos Aires, Argentina \\ ${ }^{2}$ División Paleontología de Vertebrados, Museo de La Plata. Paseo del Bosque s/n B1900FWA, La Plata, Argentina \\ ${ }^{3}$ Facultad de Ciencias Naturales y Museo, Universidad Nacional de La Plata, La Plata, Argentina \\ ${ }^{4}$ Instituto Antártico Argentino (Dirección Nacional del Antártico), 25 de mayo 1143, San Martín, Argentina \\ jgelfo@fcnym.unlp.edu.ar
}

\begin{abstract}
Here we describe a new terrestrial mammal from the Eocene of Seymour Island (Isla Marambio) represented by a lower left third molar and assigned to a new species of Sparnotheriodontidae, an ungulate family with a broad palaeobiogeographical distribution in South America. The specimen was found in the Cucullaea I allomember of the La Meseta Formation, in a new mammalian locality (IAA 2/16). Notiolofos regueroi sp. nov. shares a brachyodont, lophoselenodont and bicrescentic molar pattern with $N$. arquinotiensis, recorded for a stratigraphic sequence of $17.5 \mathrm{Ma}$ in Antarctica. The criteria for the species differentiation are the absence of mesial and labial cingulids, the larger paraconid, the wider talonid basin, the accentuated distal projection of the hypoconulid, the centroconid development and the smaller size. Together with the astrapotherian Antarctodon sobrali, they represent the medium to large terrestrial mammals of the early Eocene Antarctic landscape that was mostly dominated by closed forests of Nothofagus. Dental wear facets and differences in their body mass are inferred and discussed as possible evidence of niche differentiation. Additionally, the presence of land mammals with Patagonian affinities in the Eocene of Antarctica reinforces the Cretaceous-Palaeocene presence of the Weddellian Isthmus, a functional land corridor between Antarctica and South America.
\end{abstract}

Received 26 April 2017, accepted 1 June 2017, first published online 11 July 2017

Key words: land mammal, Litopterna, Notiolofos, Seymour Island, Sparnotheriodontidae

\section{Introduction}

At present, the Arctic communities of the northern polar region are composed of a wide taxonomic variety of mammals. Besides seals, walruses and cetaceans, related to marine environments, terrestrial mammals represent an important part of their communities. It is possible to find herbivores such as muskox, reindeer or Arctic hares, and a variety of carnivores, such as Arctic foxes, Arctic wolves, ermine or polar bears (e.g. Nowak 1999). In contrast, the few mammals present today in the southern polar region only inhabit the seas and coastal areas of Antarctica (e.g. Nowak 1999). The complete lack of terrestrial mammals in Antarctica is a particular and unique characteristic of this continent.

During the early Palaeogene, the palaeogeographical and palaeoclimatic scenarios of Antarctica were very different. The remnants of the Gondwana supercontinent still preserved terrestrial land connections between West Antarctica, particularly the Antarctic Peninsula, and southern South America through the Scotia Arc (Reguero et al. 2014), and between East Antarctica and Australia through the Tasmanian Gateway (see chapter 3 in Goin et al. 2016). Despite discussions about the accurate time of the complete isolation of Antarctica and the appearance of the Antarctic Circumpolar Current (ACC) (e.g. Bijl et al. 2013), several palaeobiogeographical models support the land connections between Antarctica and southern continents to explain the biotic distribution (Reguero et al. 2014). In the course of these connection events and in the absence of the ACC, warm and low latitude-derived currents were thought to have covered the shores of the Antarctic continent (Exon et al. 2004). During the greenhouse conditions that prevailed from the Late Cretaceous up to the cooling events by the end of the Eocene (Zachos et al. 2001) and the major ice sheet formation, the Antarctic land experienced a warmer and more seasonal climate. These unique settings allowed an intensive mammalian exchange through the southern continents, testified by the presence of Palaeocene monotremes in Patagonia (Pascual et al. 1992), the Palaeogene metatherian radiation in South America, Antarctica and Australia (Goin et al. 2016) and the presence of South American native ungulates in Antarctica (Bond et al. 2006, 2011).

Antarctic fossils of marine and terrestrial mammals are restricted to the Eocene levels of the $\mathrm{La}$ Meseta and Submeseta formations in Seymour Island (Isla 


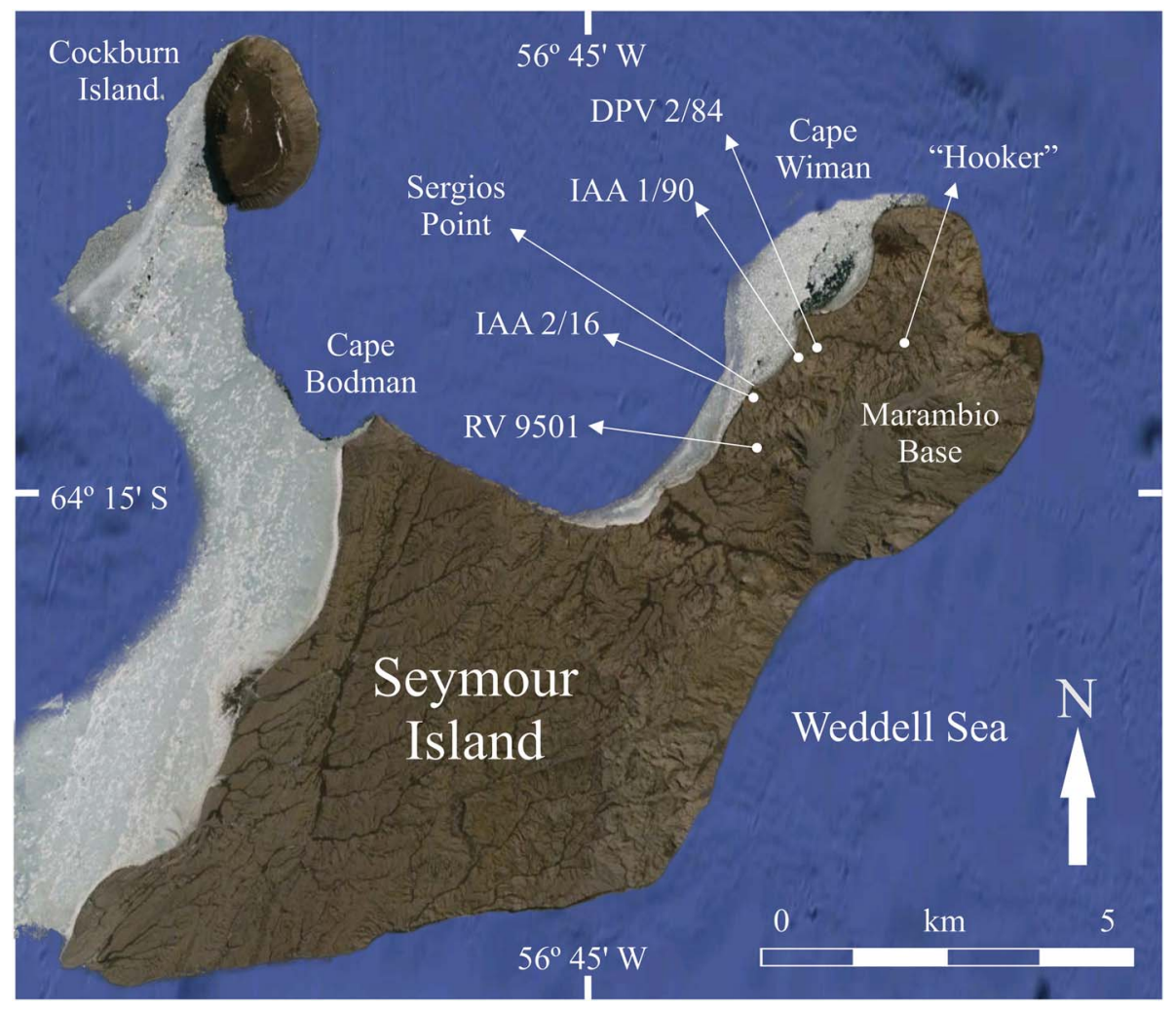

Fig. 1. Map of Seymour Island (Isla Marambio) showing the main localities mentioned in the text. Modified from satellite image dated 24 October 2016 from Google Earth Pro (version 6.2.2.6613).

Marambio) (Fig. 1) east of the Antarctic Peninsula (Montes et al. 2013, Reguero et al. 2013). Antarctic fossils of terrestrial mammals are represented by gondwanatheres, dryolestoids?, xenarthrans, a wide diversity of 'opossum-like' metatherians, litopterns (sparnotheriodontids) and astrapotheriids (see an updated list in Reguero et al. 2013).

Sparnotheriodontids are a group of extinct herbivorous terrestrial mammals, widely distributed geographically and characteristic of the Eocene outcrops of South America and West Antarctica (Gelfo 2016). They were considered as part of the South American radiation of Condylarthra (Cifelli 1993), the traditional category which established the world wide stereotypical view of the archetypal ungulate. However, with the standardization of cladistic classification, it was clear enough that Condylarthra were not a natural group but an artificial cluster of extinct and ancient taxa of different lineages. Sparnotheriodontidae are better understood as a successful family of the Palaeogene Litopterna radiation (Bond et al. 2006, Gelfo 2016). They are medium (e.g. Phoradiadius) to large (e.g. Sparnotheriodon) litopterns characterized by the presence of complete and close dental series, with brachyodont teeth, lophobunoselenodonty in the upper molars and lophoselenodonty with bicrescentic surfaces in lower ones. Aside from Antarctica, they are known from isolated teeth and a few jaw remains from several Argentinean localities, such as Cañadón Vaca and Paso del Sapo in Patagonia and Divisadero Largo in Mendoza province, as well as from the Itaboraí fissure fills in Rio de Janeiro, Brazil.

The first sparnotheriodontid known from Antarctica was an isolated upper molar (MLP 90-1-20-1) from the Eocene levels of the La Meseta Formation. Together with other specimens collected in successive Instituto Antártico Argentino-Dirección Nacional del Antártico (IAA-DNA) field trips, this sparnotheriodontid was described as a new species of Victorlemoinea (Marenssi et al. 1994), a characteristic genus previously known from the early Eocene outcrops of South America. This genus is represented by several species, including $V$. labyrinthica Ameghino, $V$. emarginata Ameghino and $V$. longidens Ameghino from the type locality west of Río Chico, later identified as Cañadón Vaca, Chubut province, Argentina, and $V$. prototypica Paula-Couto from São José de Itaboraí, Brazil. Later, the endemic nature of the Antarctic sparnotheriodontid was recognized (Bond, personal communication in Reguero et al. 1998) and was described as Notolophus arquinotiensis Bond et al. 2006, then replaced by Notiolofos (Bond et al. 2009) since the genus name was preoccupied. Notolophus arquinotiensis was recorded through different allomembers of the La Meseta 


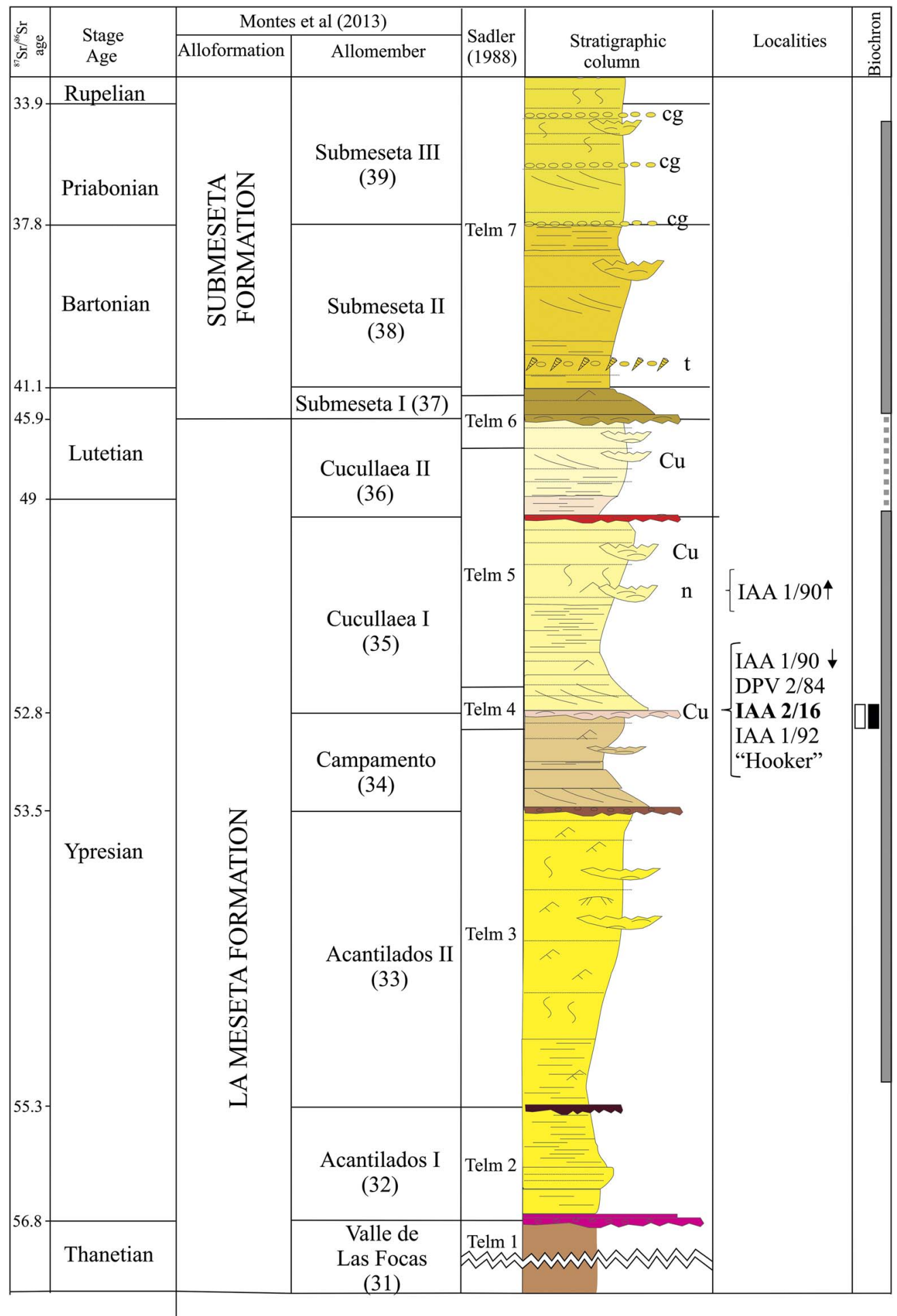

cg: conglomerates; t: sandstone with Turritella; Cu: Cucullaea level; n: Natica level;

\: Notiolofos arquinotiensis; I: Notiolofos regueroi; $\square$ : Antarctodon sobrali; , n a : : pseudoextinction

Fig. 2. Stratigraphic section of the La Meseta and Submeseta formations and biochron of Antarctic ungulates. 
and Submeseta formations (Montes et al. 2013). Through most of the stratigraphic sequence, the presence of this species involves a time span of $17.5 \mathrm{Ma}$ from the early Eocene (Ypresian) up to the Oligocene (Rupelian), and suggests a morphological stasis of dental size and traits, higher than those already recorded for extinct mammals (Gelfo 2016). The morphological stasis, also present among Eocene Antarctic penguins (Acosta Hospitaleche et al. 2013), was explained using the 'Plus ça change' model, which indicates that morphological stasis and punctuated equilibrium were the usual responses to widely fluctuating physical environments such as those characteristic of temperate regions and shallow waters (Gelfo 2016).

In the present contribution, a new species of Notiolofos from the Cucullaea I allomember of the La Meseta Formation in the locality IAA $2 / 16$ is described and the implications of its record and the dispersal of South American native ungulates in Antarctica are discussed.

\section{Materials and methods}

Specimens used in the comparisons include $N$. arquinotiensis MLP 01-I-1-1 right m3, Sparnotheriodon epsilonoides Soria MACN 18225 right and left lower jaw, Phoradiadius divortiensis Simpson, Minoprio \& Patterson MLP 87-II-20-39 left $\mathrm{m} 3$ and MLP 87-II-20-72 skull and lower jaw with right $\mathrm{p} 2-\mathrm{m} 3$ and $\mathrm{m} 2-\mathrm{m} 3, V$. prototypica MN $1485 \mathrm{~V}, \mathrm{MN} 1490 \mathrm{~V}$ and MN1483V, Victorlemoinea sp. AMNH 28467 right $\mathrm{m} 3, V$. longidens MACN A-10670 right m1-2?, Tetramerorhinus prosistens (Ameghino) MLP 82-VI-3-2 right and left jaw with p3-m3, and Lophogonodon paranensis Ameghino MLP 52-X-1-72 left jaw with $\mathrm{p} 4-\mathrm{m} 3$.

Measurements of $P$. divortiensis are from López (2008), whereas those of $S$. epsilonoides and $N$. arquinotiensis are from Gelfo (2016, tables $1 \& 2$ ). It should be noted that there is a mistake in the caption of the fig. 3 in Gelfo (2016) as the colours for $S$. epsilonoides and Meniscotherium chamense should be reversed. Dental nomenclature follows previous observations (Gelfo 2016), whereas descriptions of dental wear facets follow those of Butler (1952). For body mass estimation, the equation regressions of Janis (1990), Damuth (1990) and Scarano et al. (2011) were used.

\section{Abbreviations}

MLP = División Paleontología Vertebrados del Museo de La Plata (Buenos Aires), AMNH = American Museum of Natural History (New York, NY), DNA = Dirección Nacional del Antártico (Buenos Aires), IAA = Instituto Antártico Argentino (Buenos Aires), IAA-PV= Repositorio Paleontología Vertebrados, Instituto Antártico Argentino, MACN $=$ Museo Argentino de Ciencias Naturales (Buenos Aires), $\mathrm{MN}=$ Museu Nacional, Universidade Federal do Rio de Janeiro.

\section{Geographical and geological setting}

The geology of James Ross Basin, particularly of Isla Marambio, has been studied for more than a century (see Sadler 1988, Marenssi et al. 1998). The basin includes an important stratigraphic sequence of Upper Cretaceous and Palaeogene marine sedimentary rocks which, from base to top, comprise the Gustav (Aptian-Coniacian), Marambio (Santonian-Danian) and Seymour Island (Selandian-Rupelian) groups (Montes et al. 2013, Reguero et al. 2013). The La Meseta Formation, named and divided in three units by Elliot \& Trautman (1982), is part of the Seymour Island Group and crops out in the northern part of the island. The unit is composed of sandstones and mudstones with interbedded shell-rich conglomerates. It was divided by Sadler (1988) into seven numbered units (Telm 1 through Telm 7) and later organized into erosionally based internal units or allomembers (Fig. 2; Marenssi et al. 1998). From base to top, the present recognized allomembers of the $\mathrm{La}$ Meseta Formation include: Valle de Las Focas, Acantilados I, Acantilados II, Campamento, Cucullaea I and Cucullaea II (Montes et al. 2013). During the Eocene, these units were deposited in deltaic, estuarine and shallow marine settings, mostly within a NW-SE trending valley. The Submeseta allomember, (Marenssi et al. 1998), which is equivalent to Telm 7 of Sadler (1988), was recognized as the Submeseta Formation (Montes et al. 2013).

The tooth IAA-PV 173 holotype of the new species described here came from the Cucullaea I allomember of the La Meseta Formation, at the locality IAA 2/16, named for the low hills placed S-SW from Sergios Point near the coast of López de Bertodano Bay in Isla Marambio (Fig. 1; Montes et al. 2013). From base to top, the low hills of IAA 2/16 are formed by the Campamento allomember and the basal conglomeratic shell bed of the Cucullaea I allomember, equivalent to Telm 4 of Sadler (1988). This unit is the top of the exposed sediments in IAA 2/16 and forms an extensive and flat surface over the mentioned hills, mapped as the level $35 \mathrm{Cu}$ in Montes et al. (2013). A petrological analysis of the complete sequence of the $\mathrm{La}$ Meseta Formation indicates that there was an intense reworking at the unconformable base of Cucullaea I as well as in some parts of other allomembers (Marenssi et al. 2002). A similar conclusion was reached from the faunal analysis of Telm 4 equivalent to the base of the Cucullaea I allomember. As veneroid pelecypods in Cucullaea I are only common in the basal horizon conglomerate (i.e. $35 \mathrm{Cu}$ ), they are very frequently found in the underlying Campamento allomember. This was interpreted by reworking and winnowing of the underlying deposits during an interval in which critical ecological factors changed (Sadler 1988). As a consequence, there is no certainty that the remains found in the basal coquinoid 


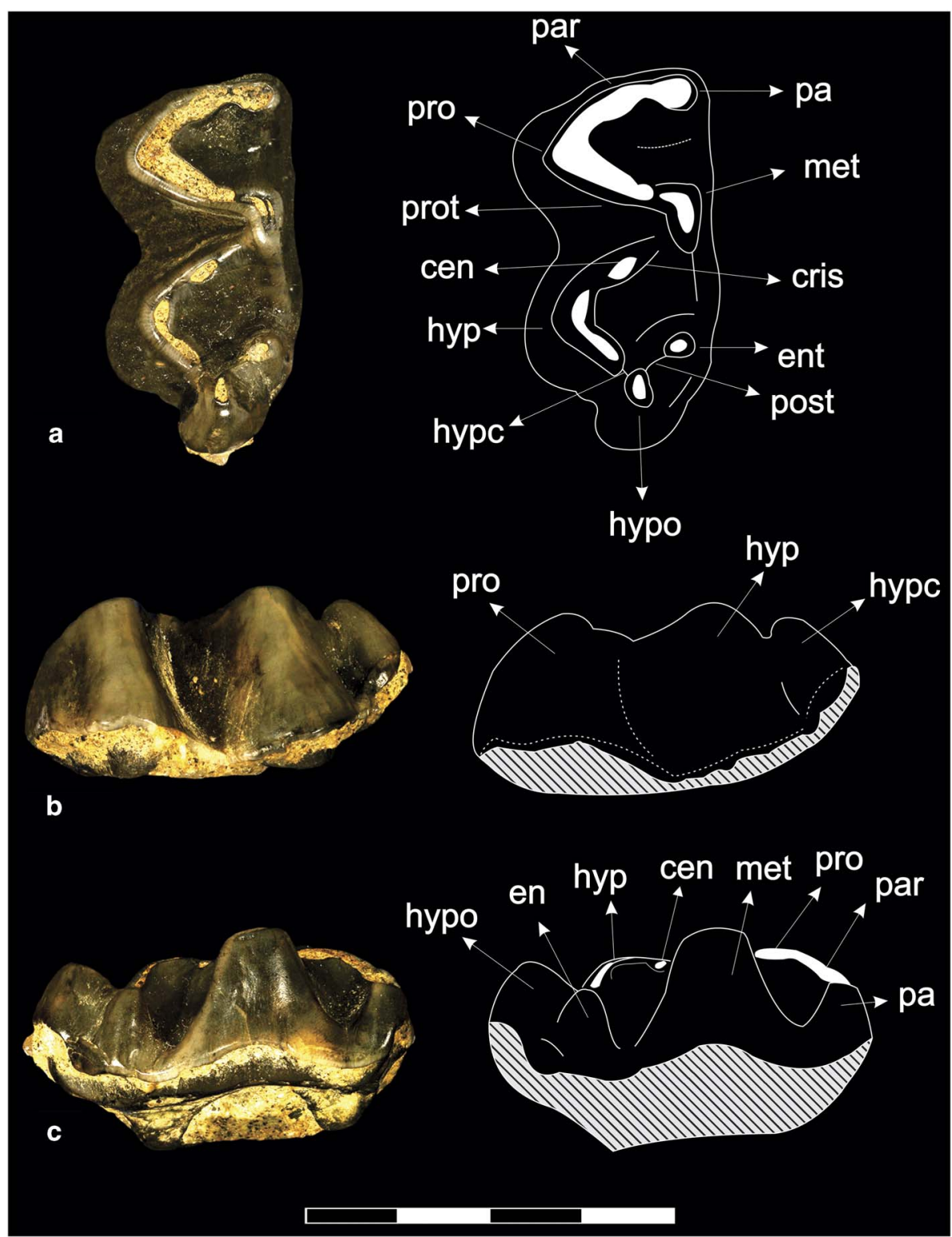

Fig. 3. Notiolofos regueroi IAA-PV 173. a. Occlusal, b. labial and c. lingual views. cen = centroconid, cris = cristid obliqua, en $=$ entoconid, hyp $=$ hypoconid, hypo $=$ hypoconulid, hypc $=$ hypocristid, met $=$ metaconid, pa $=$ paraconid, par $=$ paralophid, post $=$ postcristid, pro $=$ protoconid, prot $=$ protolophid. Scale: $20 \mathrm{~mm}$.

conglomerate of Cucullaea I (or Telm 4), as the specimen here studied, were not originally from the lower Campamento allomember.

\section{Systematic palaeontology}

Mammalia L. 1758

Laurasiatheria Waddell et al. 1999

Panperissodactyla Welker et al. 2015

Litopterna Ameghino 1889

Sparnotheriodontidae Soria 1980

Notiolofos Bond, Reguero, Vizcaíno, Marenssi and

Ortiz-Jaureguizar 2009

Notiolofos regueroi sp. nov. (Fig. 3)

\section{Holotype}

Isolated complete left lower third molar, IAA-PV 173.

\section{Etymology}

Named after Marcelo Reguero, researcher of the IAA and MLP, for his outstanding contribution to the progress of the Antarctic palaeontological knowledge.

\section{Geographical and stratigraphic provenance}

Locality IAA 2/16 in Isla Marambio, Antarctica. Lower level of coquina of the Cucullaea I allomember, La Meseta Formation (upper Ypresian). 


\section{Diagnosis}

Sparnotheriodontid of less than half the size of $N$. arquinotiensis. It differs from all known members of the family in the following list of characters: absence of mesial and labial cingulids, larger paraconid in the paracristid, wider talonid basin, hypoconulid more distally projected and isolated from the rest of the talonid as a third lobe, more lingual entoconid, short, low and well developed postcristid, and the presence of centroconid over the cristid obliqua.

\section{Comparative description}

Notiolofos regueroi is only known by an isolated left $\mathrm{m} 3$ without roots and with scarce wear over its enamel, with a mesiodistal length of $20.06 \mathrm{~mm}$ and labiolingual width of $10.42 \mathrm{~mm}$. As in all known $\mathrm{m} 3$ of sparnotheriodontids, the trigonid is mesiodistally shorter than the talonid, but in contrast to that observed in $N$. arquinotiensis and $S$. epsilonoides the trigonid and the talonid are almost equal in width (Fig. 3). The crescent aspect of the trigonid in IAA-PV 173 is better developed than that of the talonid, which shows less wear and thus clear cusp identification. The trigonid valley is wider than in $N$. arquinotiensis, probably due to less wear, and, as in all sparnotheriodontids, lingually open in the absence of the metacristid. The metaconid is the highest cusp with a flat lingual wall of enamel (Fig. 3c) comparable to that present in the rest of the family and even in other litopterns such as Proterotheriidae. In the $\mathrm{m} 3$ of $N$. arquinotiensis (MLP 01-I-1-1) there is a wide descending cristid distal to the metaconid (Bond et al. 2006 ) with a strong wear facet related to facet 3 of Butler (1952). In contrast, in $N$. regueroi the cristid is less developed, with a more pronounced slope and no wear facet. Besides sparnotheriodontids, a similar crest distal to the metaconid is present among notoungulates and a small cusp is sometimes present in archaic ungulates such as Northern Hemisphere Phenacodontidae and South American Didolodontidae. The homologies between the cristid and the cusp distal to the metaconid are not clear and different names have been used for them (e.g. metastylid, postmetastylid, metaconulid, tuberculum intermedium).

Although the paraconid in $N$. regueroi is joined to the paralophid because of wear, its outline indicates the presence of a well-defined rounded cusp (Fig. 1a), similar to that of $N$. arquinotiensis but larger than that of $S$. epsilonoides. Among Victorlemoinea specimens, none of the available teeth of $V$. prototypica were clearly identified as an $\mathrm{m} 3$ to establish a comparison with the same locus. Despite the differences in wear over the occlusal surface of isolated molars of $V$. prototypica, there is a wide variation in paraconid development, from a large cusp (e.g. MN $1485 \mathrm{~V}, \mathrm{MN} 1490 \mathrm{~V}$ ) up to the complete integration of this cusp to the paralophid (e.g. $\mathrm{MN1483V).} \mathrm{In} \mathrm{the} \mathrm{isolated} \mathrm{m} 3$ from Cañadón Vaca in Patagonia, assigned to Victorlemoinea sp. (AMNH 28467), the paralophid is expanded in its lingual side, suggesting the presence of a strong paraconid which was integrated to the lophid by wear. In P. divortiensis, there is a right $\mathrm{m} 3$ not completely erupted (MLP 87-II-20-72), which has a strong and pointed end cusp, higher than the paralophid. As in the rest of sparnotheriodontids, the protoconid of $N$. regueroi is lower in height than the metaconid and the paralophid is lower than the protolophid.

In $N$. regueroi, the ectoflexid clearly separates the trigonid and the talonid, and transversally reaches the metaconid, flanked by the distal wall of the protoconid/ protolophid, and the mesial side of the hypoconid/cristid obliqua (Fig. 3a \& b). There are no cuspules in the ectoflexid valley as those observed in $N$. arquinotiensis (Bond et al. 2006).

In contrast to that observed in most known sparnotheriodontids, in which the wear hides the main cusps of the talonid in a ' $\mathrm{V}$ ' shaped structure, in $N$. regueroi the principal cusps are well differentiated. The hypoconid is the largest cusp of the talonid, which is lower than the protoconid. The cristid obliqua of $N$. regueroi has almost no trace of wear, except in the middle position, where a small centroconid is present. This cusp, characteristic of several Didolodontidae (e.g. Didolodus), is not evident in other sparnotheriodontids, which, except for $P$. divortiensis, have an important wear over the cristid obliqua. In contrast to the mesial part of the talonid, there is a more accentuated wear in the hypolophid of $N$. regueroi. The lophid descends distally up to the base of the hypoconulid, which is distinguished from that of $N$. arquinotiensis for being projected much further distally as a third lobe. This feature has not been observed among sparnotheriodontids but in other litopterns such as Proterotheriidae. In Tetramerorhinus prosistens (MLP 82-VI-3-2) or Lophogonodon paranensis (MLP 52-X-1-72) for example, the $\mathrm{m} 3$ of these forms has a third lobe but differs from that of $N$. regueroi in the development of the lingual cingulid and because the postcristid descends from the apex of the hypoconulid to the distolabial base of the entoconid not to the apex of the cusp. When the wear in proterotheriids is pronounced the hypoconulid reaches the entoconid mesiolingually forming a small crescent structure of dentine, very different from that observed in sparnotheriodontids.

The entoconid is smaller and rounded, in contrast to the hypoconulid, which is mesiodistally elongated. Both cusps are related by a short and sharp postcristid without trace of wear. Among sparnotheriodontid molars and particularly in $\mathrm{m} 3$, the hypoconulid and the entoconid are not usually so clearly defined as in $N$. regueroi. 
In $P$. divortiensis, the entoconid is larger and well-defined but the hypoconulid is reduced and integrated to the hypolophid. There is no available $\mathrm{m} 3$ for $V$. longidens (MACN A-10670), but there is a strong entoconid in the $\mathrm{ml}$ which is part of the hypolophid with the hypoconulid, as a consequence of wear. A similar development of the entoconid is also observed in $V$. prototypica, as in Sparnotheriodon it is much reduced, but still individualized as a short mesial projection of the hypolophid.

Parallel to the postcristid but in the lingual base of the talonid, a faint and short labial cingulid runs from the hypoconulid up to the entoconid. This is the only cingulid visible in $N$. regueroi in contrast to that observed in lower p1-m3 of sparnotheriodontids and particularly in the $\mathrm{m} 3$ of $N$. arquinotiensis. In these teeth, the labial and lingual cingulids are variably developed, being the lingual usually weaker than the labial cingulid. Although the comparable labial side of the talonid of the only available $\mathrm{m} 3$ (MLP 01I-1-1) of $N$. arquinotiensis is broken, a faint cingulid is identified on the lingual side. The lingual cingulid is located near the mesial base of the metaconid. The mesial cingulid, probably in continuity with the lingual one, extends transversely, with the lingual portion higher and pointing to the paralophid. The labial cingulid extends from the distal base of the protoconid up to the hypoconulid.

The enamel in $N$. regueroi presents vertically oriented Hunter-Schreger bands (HSBs) as in $N$. arquinotiensis but, in contrast to it, the enamel surface is smooth not wrinkled, except for the lingual area limited by the hypoconulid, entoconid, postcristid and the remnant of the lingual cingulid.

\section{Taphonomic conditions}

The most prolific level for the presence of terrestrial mammals in the Cenozoic sequence of the Seymour Island Group is Cucullaea I allomember of the La Meseta Formation. There is a wide variety of terrestrial mammals from different localities where this unit crops out (see updated list in Reguero et al. 2013). The Cucullaea I allomember crops out all around the foothills of the north plateau of Isla Marambio, except for a short portion of the northeast of the island. Most of the known land mammals from this unit came from the naticid bed at the middle portion of the allomember, which is equivalent to Telm 5 . Notiolofos regueroi was found in the most basal conglomeratic shell bed of Cucullaea I (Telm 4), referred to as $35 \mathrm{Cu}$ by Montes et al. (2013), which was reworked from the underlying Campamento allomember (Sadler 1988). The vertebrate fauna known for this particular level is best represented in another locality, DPV 2/84 (Figs 1 \& 2), where several plates assigned to a Dermochelyidae turtle (de la Fuente et al. 1995), the remains of a jaw of a pelagiceti basilosaurid cetacean (Buono et al. 2016) and isolated teeth of the astrapotherian ungulate Antarctodon sobrali Bond et al. were found. Additional dermochelyid remains were also found in this level but in the locality RV 9501 (Figs 1 \& 2; Albright et al. 2003).

Although the conglomeratic shell beds from where these vertebrates come were reworked from the underlying Campamento allomember (Sadler 1988), the tooth of $N$. regueroi exhibits very few erosion or transportation signs, which are limited to the absence of roots and the soft and rounded edge of enamel near the tooth neck. The preservation is indistinguishable from that observed in specimens of $N$. arquinotiensis from the upper naticid bed of the same unit (i.e. Cucullaea I allomember), for example at IAA 1-90 (Figs $1 \& 2$ ).

\section{Stratigraphic considerations}

As $N$. regueroi is stratigraphically restricted, there is a broad record of $N$. arquinotiensis which is present from Acantilados II of the La Meseta Formation up to the Submeseta III allomember of the Submeseta Formation (Gelfo 2016). Its absence from Cucullaea II allomember seems to be due to taphonomic conditions, considering the low diversity of all fossil vertebrates in contrast to adjacent units (Fig. 2). Even penguins and sharks, which are the most notorious vertebrate remains in the La Meseta Formation, have low abundance in this last unit.

The isotopic and palaeomagnetic calibration of the units (Montes et al. 2013) indicates a relatively continuous record of $N$. arquinotiensis during most of the Eocene. The oldest record came from the Ypresian at the basal marine horizon of the Acantilados II allomember of the La Meseta Formation (Telm 3), with its base dated at $55.3 \mathrm{Ma}$ (Montes et al. 2013). The youngest record is from the Priabonian at the upper third of Telm 7 sensu Vizcaíno et al. (1997), i.e. Submeseta III allomember (Submeseta Formation) with its base dated at $37.8 \mathrm{Ma}$ (Montes et al. 2013). Based on this stratigraphic distribution and the dental morphology of $N$. arquinotiensis, an evolutionary stasis event of at least $17.5 \mathrm{~m} . \mathrm{y}$. in duration has been suggested (Gelfo 2016).

Notiolofos regueroi gives another perspective from which to analyse the morphological stability of $N$. arquinotiensis. Since the specimen IAA-PV 173 is an $\mathrm{m} 3$ of a brachyodont mammal, there is certainty that it belonged to an adult individual of more or less half the size of that indicated by the $\mathrm{m} 3$ of $N$. arquinotiensis. This indicates the coexistence of two sparnotheriodontid ungulates, at least for the same stratigraphic level (i.e. Cucullaea I allomember) during the early Eocene, but not a replacement through time. The biochron of $N$. arquinotiensis is much wider, appearing previously and considerably surpassing the stratigraphic occurrence of $N$. regueroi limited currently to the lower levels of Cucullaea I allomember (Fig. 2). 


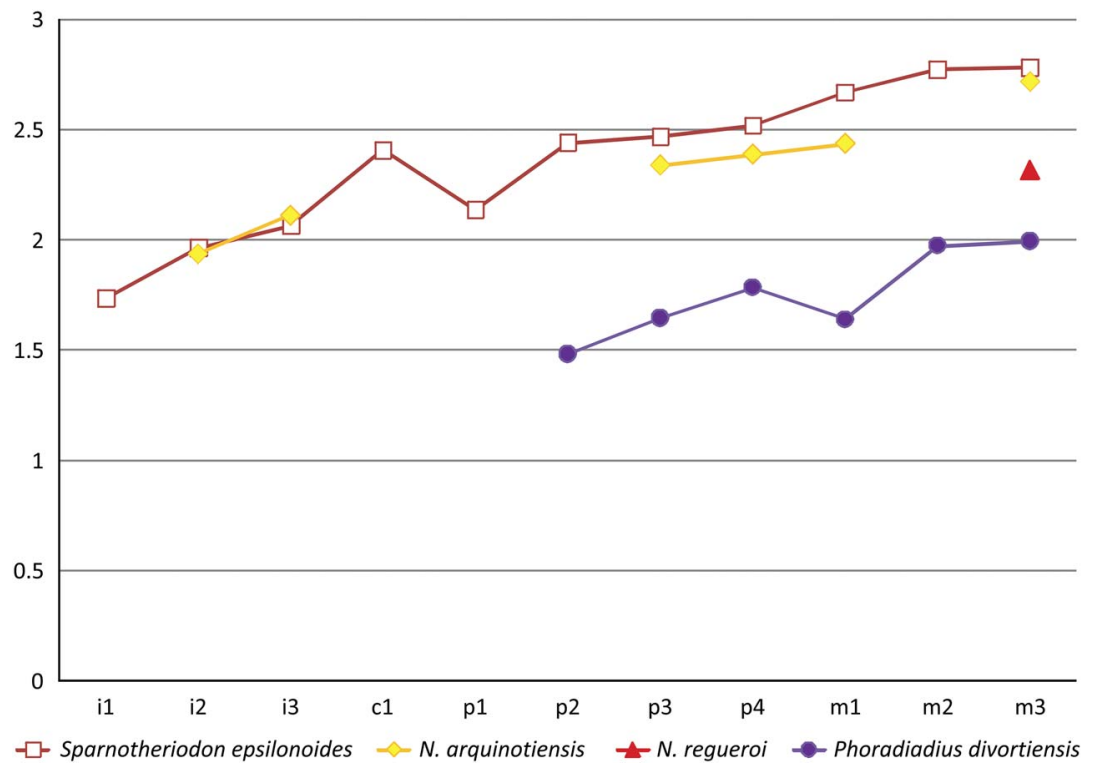

Fig. 4. Profile dental series with the occlusal areas of the known teeth of main Sparnotheriodontidae. $\log _{10}$ of occlusal area surface in the vertical axis and tooth loci in the horizontal axis.

The temporal calibration of the Seymour Island Group is also particularly relevant to consider the stratigraphic distribution of Sparnotheriodontidae. Although the palaeomagnetic calibration of Montes et al. (2013) is followed here, there is not complete agreement about the age of the La Meseta and Submeseta formations. Several different temporal inferences have been proposed using a wide variety of methods and different parts of the sequence. Considering the palynoflora, mainly dinoflagellate cyst assemblages of the first $168 \mathrm{~m}$ of the La Meseta Formation, in Valle de Las Focas (Telm 1) and Acantilados I (Telm 2), the inferred age was no older than late early Eocene and possibly as young as mid to late Eocene (Cocozza \& Clarke 1992). Recently, for Acantilados I, the presence of calcareous nannofossils, characteristic of the biozones NP17 and NP18, was used to infer a Bartonian-Priabonian age (Concheyro et al. 2016). The uppermost part of the Seymour Island Group, the Submeseta Formation (top of Telm 7), was considered as latest Eocene-earliest Oligocene (33.57-34.78 Ma) in age according to different ${ }^{87} \mathrm{Sr} /{ }^{86} \mathrm{Sr}$ isotope analyses (Dingle \& Lavelle 1998, Ivany et al. 2006). The marine strontium isotope curve oscillation during the Eocene was used by Dutton et al. (2002) to infer an Ypresian age for Telm 2 (50.53 Ma), a Lutetian age for Telm 5 (between 44.54 and $47.35 \mathrm{Ma}$ ) and a Priabonian age for Telm 7 (between 36.13 and $34.96 \mathrm{Ma}$ ).

If the sediments of Submeseta III are Priabonian in age (Montes et al. 2013) as for Acantilados I allomember (Concheyro et al. 2016), an important temporal briefness of the stratigraphic sequence of the upper Seymour Island Group should be considered. Nevertheless, there is no geological evidence to support that the $560 \mathrm{~m}$ of sediments from the base of Acantilados I allomember up to the roof of Submeseta III allomember (Marenssi et al. 1998) represents a short time span with high sedimentation rates.

\section{Antarctic ungulates}

Terrestrial mammals with South American affinities in Antarctica involves not only ungulates but also marsupials, gondwanatherians and xenarthrans (see list in Reguero et al. 2013). Their presence was explained by a dispersal event through the Weddellian Isthmus, a land connection between the continents which is supposed to have been functional at least up to the late Palaeocene (Reguero et al. 2014). The Weddellian Isthmus also explains the record of monotremes in the early Palaeocene (Danian) of Patagonia (Pascual et al. 1992) and the origin of Australian marsupials (see Chapter 3 in Goin et al. 2016). The time up to when the terrestrial bridge was functional for dispersal events also matches with the absence of Notoungulata in Antarctica, which are the most successful ungulate group in the Cenozoic of South America. Notoungulates were first recorded in the early Palaeocene of Tiupampa (Bolovia); however, according to the latest isotopic calibrations, they were not recorded in Patagonia up to the early Eocene. Their radiation into higher latitudes of southern South America seems to be coincident with the interruption of the Weddellian Isthmus. In addition, this land bridge could have functioned as an ecological filter for Palaeocene South American mammals (i.e. Kollpaniinae, Didolodontidae, Xenungulata) not present in the Antarctic fossil record. 
Little is known of extinct Antarctic land mammals. This is because of the fragmentary nature of their remains, mostly represented by isolated teeth and the few outcrops exposed without ice cover in this continent. The body mass of mammals is highly correlated with different molar sizes as well as with life history variables (e.g. lifespan, reproduction age, gestation time, weaning age, litter number). Based on equations models, the range of body size among terrestrial mammals of the La Meseta and Submeseta formations was inferred to vary from small marsupials of $0.05-0.3 \mathrm{~kg}$ up to medium and large ungulates (Vizcaíno et al. 1998).

A comparison of the occlusal surface area of sparnotheriodontids indicates that although $N$. regueroi is larger than $P$. divortiensis it is smaller than $N$. arquinotiensis and S. epsilonoides (Fig. 4). In the case of the two Notiolofos species, direct comparison of measurements between teeth of the same locus (i.e. m3) of adult individuals indicates an evident difference in size. The body mass inference for $N$. arquinotiensis is based on a large sample of teeth, but there is only an isolated $\mathrm{m} 3$ available for $N$. regueroi. The use of $\mathrm{m} 3$ in these inferences has been criticized for being less accurate than other measurements, when a wide sample of equations and postcranial and dental measurements of notoungulates have been analysed (Elissamburu 2012). It should be highlighted that the body mass estimations for $N$. regueroi could be less accurate than those previously obtained for $N$. arquinotiensis, whose body mass was estimated between 395-400 kg (Vizcaíno et al. 1998) based on Damuth (1990). In order to replicate the possible error, regression equations with the third lower molar length are used here for both taxa, so the body mass estimated starts with the same premise.

The body mass estimation for the most complete $\mathrm{m} 3$ of $N$. arquinotiensis (MLP 01-I-1-1) is $230.95 \mathrm{~kg}$ following the model of Janis (1990), $186.28 \mathrm{~kg}$ based on Damuth (1990) and $56.10 \mathrm{~kg}$ using the equations of Scarano et al. (2011). While for the $N$. regueroi specimen, the values are $57.86 \mathrm{~kg}$, $50.57 \mathrm{~kg}$ and $25.07 \mathrm{~kg}$, respectively. The differences between these equations reflects the fact that the model of Scarano et al. (2011) is more precise for small mammals, since the regression equations were created using herbivorous ungulates with a body mass of less than $13.5 \mathrm{~kg}$. Particularly for $N$. arquinotiensis, the value of $56.10 \mathrm{~kg}$ from Scarano et al. (2011) seems to be an underestimation, if compared with the previous inference of Vizcaíno et al. (1998) or the new values using the m3 length. However, it is difficult to be sure about the accuracy with the smallest tooth of $N$. regueroi. Therefore, we prefer to be cautious and consider a body mass range between the lowest and highest inferred values.

The two species of Notiolofos plus the astrapotherian A. sobrali, with an inferred body mass of $18.5-38 \mathrm{~kg}$ (Vizcaíno et al. 1998), are the largest terrestrial herbivorous mammals recorded for the Eocene of Antarctica. These ungulates share a comparable dental structure with the development of lophs, brachyodont teeth and with vertical orientation of HSBs in the enamel (Bond et al. 2011). The HSBs have a particular orientation, common in extinct ungulates but only known in Rhinocerotidae among extant ones. These dental features are more appropriate for feeding on plant leaves with few abrasive elements than on grass, fruits or seeds. Based on these arguments, they were interpreted as ungulates adapted to forested habitats, such as the closed forests dominated by Nothofagus inferred for Cucullaea I allomember (Reguero et al. 1998).

The coexistence of terrestrial mammals with similar characteristics in West Antarctica raises the question about the possibility of a niche differentiation to avoid competition. Although a complete analysis of this topic is beyond the scope of the present work, some interesting differences related to dental morphology and chewing could be related to resource partitioning.

The Antarctodon tooth, assigned to a $\mathrm{p} 4$ or $\mathrm{m} 1$ (Bond et al. 2011), differs from those of Notiolofos species in the presence of a larger trigonid height with respect to the talonid. This is limited by the strong and tall wall of the protolophid (described as metalophid by Bond et al. (2011)) that connects the protoconid and the metaconid, dividing the tooth into two different levels. There is a strong and vertical postvallid, in which a small wear facet is present distal to the protoconid. Compared with the wear facets described by Butler (1952), the position resembles the labial portion of facet 2 . Two other facets comparable with those described by Butler (1952) are present in Antarctodon. Facet 1, which is a long rim from the labial edge of the high protoconid and paracristid up to the sizeable cuspule placed in the mesial side of the trigonid and facet 7 , over the distal part of the hypocristid, which joined the hypoconid and the hypoconulid.

In contrast, the $\mathrm{m} 3$ of $N$. arquinotiensis has a stronger degree of development of facet 1 and particularly of facet 2 , which extends through the length of the protolophid. This species also differs in the presence of facet 3, placed distal to the metaconid and with a strong and rounded development and a long but narrow facet 6 , over the labial side of the cristid obliqua. Facet 7, which is restricted to the more distal part of the hypocristid, is comparable to that present in Antarctodon.

In $N$. regueroi, the wear is not so pronounced and the facets are hardly distinguished. The clearest facet is facet 2 with a development similar to that in $N$. arquinotiensis, which will probably share a strong similarity with an advanced wear.

The differences between wear facets, the trigonid and talonid height, and the lophid development between Antarctodon and Notiolofos are related to differences in chewing movement and probably to the kind of plant resources they processed. In contrast, the distinction between $N$. arquinotiensis and $N$. regueroi seems to be 
more related to their body mass than to their teeth, and allows inference of mechanical processing of food.

\section{Conclusion}

During its deposition, the main marine sequence of the Seymour Island Group received an important contribution of continental sediments. The record of leaves, wood and a Grossulariaceae flower in La Meseta levels is evidence of the presence a forested terrain nearby. The wide diversity of terrestrial mammals, mainly represented by isolated teeth found in the same outcrops, probably came from the same source. Although the good preservation of all these land biota and, in some cases, the few or null evidence of transportation suggest the presence of a not yet detected continental level in the La Meseta Formation; however, there is no geological evidence to support this hypothesis.

Notiolofos regueroi, represented by an isolated left $\mathrm{m} 3$ (IAA-PV 173), is the second sparnotheriodontid litoptern and the third ungulate recorded in the lower levels of the Cucullaea I allomember of the La Meseta Formation. With an estimated body mass of $25.07-57.86 \mathrm{~kg}$, its morphology shows clear phylogenetic affinities with other members of the family and particularly with $N$. arquinotiensis, the most common ungulate recorded in Antarctica through the La Meseta and Submeseta formations.

The presence of ungulates as well as other mammals with Patagonian affinities in the Eocene of Antarctica has been explained by the Weddellian Isthmus, which is thought to have been a functional land corridor between Antarctica and South America at least up to the late Palaeocene. The interruption of this land continuity, or at least of available nutritional resources between the continents, is supported by the lack of evidence of other Palaeogene terrestrial mammals (e.g. Notoungulata) dispersing from Patagonia to West Antarctica. However, the weakness of the previous arguments lies in the assumption that an absence in the fossil record is evidence of past events. Besides, the information from the Palaeogene terrestrial mammals in Antarctica is currently restricted to outcrops of the La Meseta and Submeseta formations at Isla Marambio. The discovery of new Antarctic localities is required to improve the knowledge of the biotic and palaeobiogeographical history of Antarctica.

\section{Acknowledgements}

This research was supported by the Instituto Antártico Argentino-Dirección Nacional del Antártico (IAADNA), and the funding: PIP 0489 and N812-UNLP Vertebrados del lapso Cretácico Superior Paleógeno de la Península Antártica y extremo sur de Patagonia (Sur del Paralelo $50^{\circ}$ ) Parte II, Directed by Marcelo Reguero. We are grateful to the Fuerza Aérea Argentina, the Base Marambio staff, and the 'tambuchero' Marco Ríos, for their logistic support in the field. The camp and fieldwork counted with the invaluable support of Carolina Acosta Hospitaleche and Jacobo Daniel. We also thank Bruno Pianzola for taking the photograph of the tooth, Victoria Eusebi for improving the English of this manuscript, and Cliff Atkins, Thomas Mörs and an anonymous reviewer for their comments and suggestions.

\section{Author contribution}

SNS and JNG participated in the Antarctic fieldwork. GML and JNG studied and interpreted the fossil. JNG coordinated the writing of the paper with the rest of the authors.

\section{References}

Acosta Hospitaleche, C., Reguero, M. \& Scarano, A. 2013. Main pathways in the evolution of the Paleogene Antarctic Sphenisciformes. Journal of South American Earth Sciences, 43, 101-111.

Albright, B.L., Woodburne, M.O., Case, J.A. \& Chaney, D.S. 2003. A leatherback sea turtle from the Eocene of Antarctica: implications for the antiquity of gigantothermy in Dermochelyidae. Journal of Vertebrate Paleontology, 23, 945-949.

Bijl, P.K., Bendle, J.A.P., Bohaty, S.M., Pross, J., Schouten, S., Tauxe, L., Stickley, C.E., McKay, R.M., Röhl, U., Olney, M., Sluiss, A., Escutia, C. \& Brinkhuis, H. 2013. Eocene cooling linked to early flow across the Tasmanian Gateway. Proceedings of the National Academy of Sciences of the United States of America, 110, 9645-9650.

Bond, M., Kramarz, A., MacPhee, R.D.E. \& Reguero, M. 2011. A new astrapothere (Mammalia, Meridiungulata) from La Meseta Formation, Seymour (Marambio) Island, and a reassessment of previous records of Antarctic astrapotheres. American Museum Novitates, 10.1206/3718.2.

Bond, M., Reguero, M.A., Vizcaíno, S.F. \& Marenssi, S.A. 2006. A new "South American ungulate" (Mammalia:: Litopterna) from the Eocene of Antarctic Peninsula. Special Publication of the Geological Society of London, No. 258, 163-176.

Bond, M., Reguero, M.A., Vizcaíno, S.F., Marenssi, S.A. \& OrtizJAUREGUIZAR, E. 2009. Short communication Notiolofos, a replacement name for Notolophus Bond, Reguero, Vizcaíno, and Marenssi, 2006, a preoccupied name. Journal of Vertebrate Paleontology, 29, 979.

Buono, M.R., Fernández, M.S., Reguero, M.A., Marenssi, S.A., Santillana, S.N. \& Mörs, T. 2016. Eocene basilosaurid whales from the la Meseta formation, Marambio (Seymour) Island, Antarctica. Ameghiniana, 53, 296-315.

Butler, M.A. 1952. The milk molars of Perissodactyla, with remarks on molar occlusion. Proceedings of the Zoological Society of London, 121, 777-817.

Cifelli, R.L. 1993. The phylogeny of the native South American ungulates. In Szalay, F.S., NovaceK, M.J. \& McKenna, M.C., eds. Mammal phylogeny, volume 2. Placentals. New York, NY: Springer, 195-216.

Cocozza, C.D. \& Clarke, C.M. 1992. Eocene microplankton from La Meseta Formation, northern Seymour Island. Antarctic Science, 4, 355-362.

Concheyro, A., Amenábar, C.R., Santillana, S., Montes, M.S. \& Nozal, F.B.M. 2016. Primer registro de nanofósiles calcáreos en la Formación La Meseta (Eoceno medio), Isla Marambio, Antártida. Proceedings of the 11 Congreso de la Asociación Paleontológica Argentina, abstract no. 126. Available at: http://www.conicet.gov.ar/ new_scp/detalle.php?keywords=\&id=20037\&congresos=yes\&detalles $=$ yes\&congr_id=6259349. 
Damuth, J. 1990. Problems in estimating body masses of archaic ungulates using dental measurements. In Damuth, J. \& Macfadden, B.J., eds. Body size in mammalian paleobiology: estimation and biological implications. Cambridge: Cambridge University Press, 229-253.

de la Fuente, M.S., Santillana, S.N. \& Marenssi, S.A. 1995. An Eocene leatherback turtle (Cryptodira: Dermochelydae) from Seymour Island, Antarctica. Studia Geologica Salmanticensia, 31, 21-34.

Dingle, R.V. \& Lavelle, M. 1998. Antarctic Peninsular cryosphere: early Oligocene (c. $30 \mathrm{Ma}$ ) initiation and a revised glacial chronology. Journal of the Geological Society, 155, 433-437.

Dutton, A.L., Lohmann, K.C. \& Zinsmeister, W.J. 2002. Stable isotope and minor element proxies for Eocene climate of Seymour Island, Antarctica. Paleoceanography, 10.1029/2000PA000593.

Elissamburu, A. 2012. Estimación de la masa corporal en géneros del Orden Notoungulata. Estudios Geológicos, 68, 91-111.

Elliot, D.H. \& Trautman, T.A. 1982. Lower Tertiary strata on Seymour Island, Antarctic Peninsula. In Craddock, C., ed. Antarctic geoscience. Madison, WI: University of Wisconsin Press, 287-297.

Exon, N.F., Kennett, J.P. \& Malone, M.J. 2004. The Cenozoic Southern Ocean: tectonics, sedimentation, and climate change between Australia and Antarctica. Washington, DC: American Geophysical Union, 151 pp.

GeLFo, J.N. 2016. Considerations about the evolutionary stasis of Notiolofos arquinotiensis (Mammalia: Sparnotheriodontidae), Eocene of Seymour Island, Antarctica. Ameghiniana, 10.5710/AMGH.14.09.2015.2934.

Goin, F.J., Woodburne, M.O., Zimicz, A.N., Martin, G.M. \& Chornogubsky, L. 2016. A brief history of South American metatherians: evolutionary contexts and intercontinental dispersals. Dordrecht: Springer, $237 \mathrm{pp}$.

Ivany, L.C., van Simaeys, S., Domack, E.W. \& Samson, SD. 2006. Evidence for an earliest Oligocene ice sheet on the Antarctic Peninsula. Geology, 10.1130/G22383.1.

JANIS, C.M. 1990. Correlation of cranial and dental variables with body size in ungulates and macropodoids. In DAMUTH, J. \& MACFADDEN, B.J. eds. Body size in mammalian paleobiology: estimation and biological implications. Cambridge: Cambridge University Press, 255-299.

López, G. M. 2008. Los ungulados de la Formación Divisadero Largo (Eoceno inferior?) de la provincia de Mendoza, Argentina: sistemática y consideraciones bioestratigráficas. Buenos Aires: Facultad de Ciencias Naturales y Muse, Universidad Nacional de La Plata, 407 pp.

Marenssi, S.A., Net, L.I. \& Santillana, S.N. 2002. Provenance, environmental and paleogeographic controls on sandstone composition in an incised-valley system: the Eocene La Meseta Formation, Seymour Island, Antarctica. Sedimentary Geology, 150, 301-321.

Marenssi, S.A., Santillana, S.N. \& Rinaldi, C. 1998. Stratigraphy of La Meseta Formation (Eocene), Marambio (Seymour) Island, Antarctica. Asociación Paleontológica Argentina Publicación Especial, No. 5, 137-146.
Marenssi, S.A., Reguero, M.A., Santillana, S.N. \& Vizcaino, S.F. 1994. Eocene land mammals from Seymour Island, Antarctica: palaeobiogeographical implications. Antarctic Science, 6, 3-15.

Montes, M., Nozal, F., Santillana, S.N., Marenssi, S.A. \& Olivero, E.B. 2013. Mapa Geológico de la isla Marambio (Seymour) escala 1:20.000 primera edición. Serie Cartográfica Geocientífica Antártica. Madrid: Instituto Geológico y Minero de España and Buenos Aires: Instituto Antártico Argentino.

NowAK, R.M. 1999. Walker's mammals of the world, Vol. 1-2. Baltimore, MD: Johns Hopkins University Press, 2015 pp.

Pascual, R., Archer, M., Jaureguizar, E.O., Prado, J.L., Godthelp, H. \& Hand, S.J. 1992. First discovery of monotremes in South America. Nature, 10.1038/356704a0.

Reguero, M., Goin, F.J., Acosta Hospitaleche, C., Dutra, T. \& Marenssi, S. 2013. Late Cretaceous/Paleogene West Antarctica terrestrial biota and its intercontinental affinities. London: Springer, $120 \mathrm{pp}$.

Reguero, M.A., Vizcaíno, S.F., Goin, F.J., Marenssi, S.A. \& Santillana, S.N. 1998. Eocene high-latitude terrestrial vertebrates from Antarctica as biogeographic evidence. Asociación Paleontológica Argentina Publicación Especial, No. 5, 185-198.

Reguero, M.A., Gelfo, J.N., López, G.M., Bond, M., Abello, A., SAntillana, S.N. \& Marenssi, S.A. 2014. Final Gondwana breakup: the Paleogene South American native ungulates and the demise of the South America-Antarctica land connection. Global and Planetary Change, 10.1016/j.gloplacha.2014.07.016.

SAdLer, P.M. 1988. Geometry and stratification of uppermost Cretaceous and paleogene units on Seymour Island, northern Antarctic Peninsula. Geological Society of America Memoirs, 169, 303-320.

Scarano, A.C., Carlini, A.A. \& Illius, A.W. 2011. Interatheriidae (Typotheria; Notoungulata), body size and paleoecology characterization. Mammalian Biology, 10.1016/j.mambio.2010.08.001.

Vizcaino, S.F., Bond, M., Reguero, M.A. \& Pascual, R. 1997. The youngest record of fossil land mammals from Antarctica: its significance on the evolution of the terrestrial environment of the Antarctic Peninsula during the late Eocene. Journal of Paleontology, 71, 348-350.

Vizcaíno, S.F., Reguero, M.A., Goin, F.J., Tambussi, C.P. \& Noriega, J.I. 1998. Community structure of the Eocene terrestrial vertebrates from Antarctic Peninsula. Asociación Paleontológica Argentina Publicación Especial, No. 5, 177-183.

Zachos, J., Pagani, M., Sloan, L., Thomas, E. \& Billups, K. 2001. Trends, rhythms, and aberrations in global climate $65 \mathrm{Ma}$ to present. Science, $10.1126 /$ science.1059412. 